\title{
The effect of Saccharomyces cerevisiae on antioxidant system of grape leaves infected by downy mildew
}

\author{
Alisa Mishko, ${ }^{*}$ and Eugene Lutsky
}

Federal State Budget Scientific Institution «North Caucasian Federal Scientific Center of Horticulture, Viticulture, Wine-making», 40 years of Victory Street, 39, 350901 Krasnodar, Russia

\begin{abstract}
In this article, results of the comparative analysis and assessment of resistance of two grape cultivars Vostorg and Muscat blanc against downy mildew disease (Plasmopara viticola) with or without the symbiote Saccharomyces cerevisiae (vine yeast) were shown. The highly resistant cultivar Vostorg with yeast pre-treatment demonstrated a high defensive capability to the pathogen due to the fast immune response. On the first day after inoculation with downy downy mildew the rapid increase in the hydrogen peroxide, which is involved the first step of the grape's defense system induction, was observed. At the same time, the upregulation of the relative expression of the PR2 protein ( $\beta$-1,3-gluconase), a key gene involved in the plant's resistance to pathogens. The oxidative burst was not detected in the susceptible cultivar Muscat blanc for the couple of hours after inoculation with downy mildew pathogen. The significant increase of the total phenols content and expression of stilbene synthase, which is an enzyme involved in the synthesis of phytoalexins, was observed in leaves of Muscat blanc. It was shown that pre-treatment of grape leaves with natural symbiote $S$. cerevisiae enhanced the immune response of the resistant cultivar Vostorg and inducted phytoalexins synthesis in the susceptible cultivar Muscat blanc.
\end{abstract}

\section{Introduction}

Saccharomyces cerevisiae Meyen ex E.C. Hansen is a natural symbiote of the grape, developing on fruits or vegetative organs. This unicellular fungus belongs to the vast group called "yeasts", which is comprised of more than 1500 species. Many of them facilitate plant growth using different mechanisms: producing the plant hormones, such as indol-3-acetic acid, inducing elevated nutrients absorption, dissolving inorganic minerals, binding iron with siderophores or competing with other pathogenic microorganisms [1-4]. Studies conducted with Saccharomyces cerevisiae showed that yeasts are able to inhibit development of pathogens, synthetize phytohormones and increase plant growth rate [5-7].

Grape is susceptible to many diseases (grey mold Botrytis cinerea, black spot disease Phomopsis viticola, anthracnose Gloeosporium ampelophagum, downy mildew Plasmopara

\footnotetext{
* Corresponding author: A. Mishko; mishko-alisa@mail.ru
} 
viticola, oidium Uncinula necator and etc.). Modern ways of reducing the susceptibility of grapevine to pathogens are aimed on using biocontrol products over pathogens and activation of the plant's defense system. Downy mildew (Plasmopara viticola Berl. et de Toni) is one of the main grape's pathogens in Southern Russia. In years with the elevated air humidity conditions, the epiphytotic development of this disease is noted. The grape's resistance to the pathogen is determined by an increase in PR-proteins content (pathogenesis-related proteins). The accumulation of different phenolic substances occurs as the result of the stress. The production of the phenylalanine ammonia lyase (PAL) can increase the plant resistance to the fungal disease [8]. Stilbene synthase (STS) is responsible for synthesis of grape phytoalexins [9]. Reactive oxygen species (ROS) can increase plant antimicrobial activity, induce a hypersensitive response, strengthening of plant's cell walls through cross-linking of polyphenols with cell wall components. ROS can also act as secondary messengers for the protective genes expression induction [10].

The aim of the current study was to evaluate differences in resistance between two grape cultivars to downy downy mildew with and without pre-treatment by symbiote Saccharomyces cerevisiae.

\section{Materials and methods}

The experiment was conducted using two grape cultivars, which differed by tolerance to downy mildew: the highly resistant cultivar Vostorg and the susceptible cultivar Muscat blanc. Grape leaves were gathered from plants, grown under sterile conditions in the growing chamber. The pre-treatment with Saccharomyces cerevisiae was carried out by adding $25 \mu 1$ of the yeast substance on leaf disks at concentration of $10^{6}$ cells $/ \mathrm{ml}$. The water served as a control. 24 hours after pre-treatment with $S$. cerevisiae the suspension of Plasmopara viticola spores was added at concentration of $3 * 10^{6}$ spores $/ \mathrm{ml}$ by spraying. The spore concentration was measured using a Goryaev chamber. The influence of $S$. cerevisiae on the grape's defence system activation was assessed after 24, 48 and 96 hours after the pre-treatment. The effect of $P$. viticola infection was evaluated after 24 and 72 hours (in the general sampling scheme of the experiment 48 and 96 hours). The infection level of downy mildew was measured by the proportion of the 50 leaf discs area with the presence of sporulation. The content of total phenols was evaluated by the Folin-Ciocalteu method with some modifications [11]. The level of cell membrane lipid peroxidation was determined by the malondialdehyde (MDA) content according to Heath R.L. and Packer L. method (1968). The $\mathrm{H}_{2} \mathrm{O}_{2}$ content was measured colorimetrically using FOX1 method [12]. Total RNA was isolated using CTAB method with modifications, developed for grape leaves [13]. Obtained RNA was used in the reverse transcription reaction for synthesis of the complementary DNA (cDNA) with oligo (dT) primer using MMLV revertase (Evrogen). Primers for the RT-PCR were assembled according to the literature: stilbene synthase (STS) [14], $\beta$-1,3-gluconase (PR2) [14], chitinase (PR3) [14], phenylalanine ammonia liase (PAL) [14] and lipoxigenase (9-LOX) [15]. Calculations of the relative gene expression were made according to $\Delta \mathrm{Ct}$ method, where reference gene is glyceroaldehyde 3-phosphatedehydrogenase (GAPDH) [16]. Statistical processing of the acquired data was conducted using program software Statistica 13.3 with application of non-parametric tests of Kolmogorov-Smirnov and MannUitni U-test for small samples. $P$ values $\leq 0.05$ were considered statistically significant. Results are presented as the means \pm standard error of 3-4 replicates.

\section{Results and Discussion}


Infected leaves (PV) of the susceptible to downy mildew cultivar Muscat blanc were characterized by an elevated hydrogen peroxide content compared to the tolerant cultivar Vostorg (Fig. 1.). At the same time, the significant increase of this parameter compared to the uninfected control was recorded after 48 hours since the pre-treatment with $S$. cerevisiae (SC) in leaves of cv. Vostorg. On the other hand, cv. Muscat blanc was characterized by maximum values in the control conditions. On the second day after inoculation with Plasmopara viticola (96 hours after pre-treatment) the concentration of $\mathrm{H}_{2} \mathrm{O}_{2}$ in infected leaves of cv. Vostorg with SC pre-treatment decreased almost 4 times and amounted to 0.8 $\mathrm{mM} / \mathrm{g} \mathrm{FW}$, while that of Muscat blanc remained in the same range from 3.7 to $4.3 \mathrm{mM} / \mathrm{g} \mathrm{FW}$.
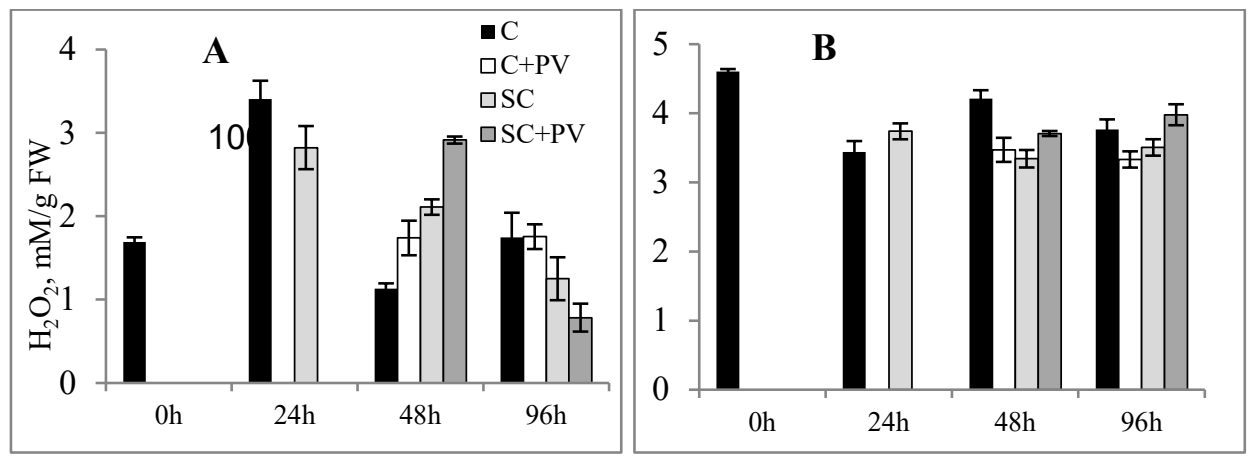

Fig. 1. Hydrogen peroxide concentration in leaves of two grape cultivars: Vostorg (A) and Muscat blanc (B) under different conditions $(\mathrm{C}-$ control, $\mathrm{C}+\mathrm{PV}-$ control $+\mathrm{PV}$ infection, $\mathrm{SC}$ - pre-treatment with SC, SC+PV - SC pre-treatment + PV infection). Treatment time - 0, 24, 48, 96 hours.

MDA content in leaves of cv. Vostorg with SC pre-treatment decreased almost 2-fold $(\sim 18 \mu \mathrm{M} / \mathrm{g} \mathrm{FW})$ after 48 hours compared to the control conditions (Fig. 2). Then, after 96 hours, levels of MDA elevated and reached control values ( $45-50 \mu \mathrm{M} / \mathrm{g} F W)$. MDA content in cv. Muscat blanc after 48 and 96 hours was relatively stable and was approximately 37 $\mu \mathrm{M} / \mathrm{g} \mathrm{FW}$, only in control conditions after 96 hours the rapid increase of the parameter to 60$70 \mu \mathrm{M} / \mathrm{g}$ FW was observed.

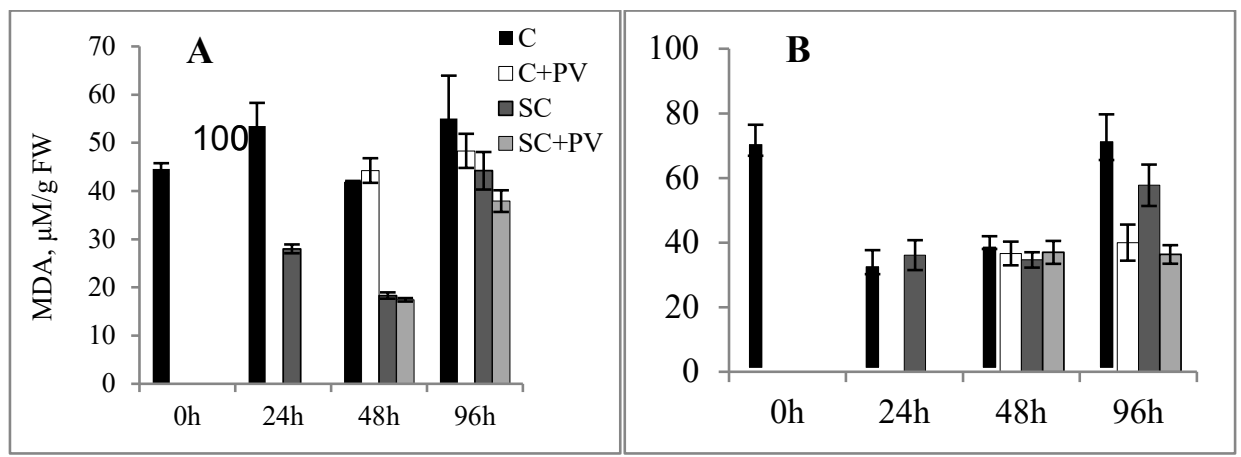

Fig. 2. MDA content in leaves of two grape cultivars: Vostorg (A) and Muscat blanc (B) under different conditions $(\mathrm{C}-$ control, $\mathrm{C}+\mathrm{PV}-$ control $+\mathrm{PV}$ infection, $\mathrm{SC}$ - pre-treatment with $\mathrm{SC}, \mathrm{SC}+\mathrm{PV}-\mathrm{SC}$ pretreatment $+\mathrm{PV}$ infection). Treatment time $-0,24,48,96$ hours.

Total phenolic content in cv. Vostorg ranged from 4.3 to $7 \mathrm{mg} / \mathrm{g}$ FW with absence of important differences (Fig. 3). In leaves of cv. Muscat blanc, after 48 hours, an increase of total phenols (2.5-fold) was noted in infected samples using SC pre-treatment compared to control leaves infected with downy mildew. 

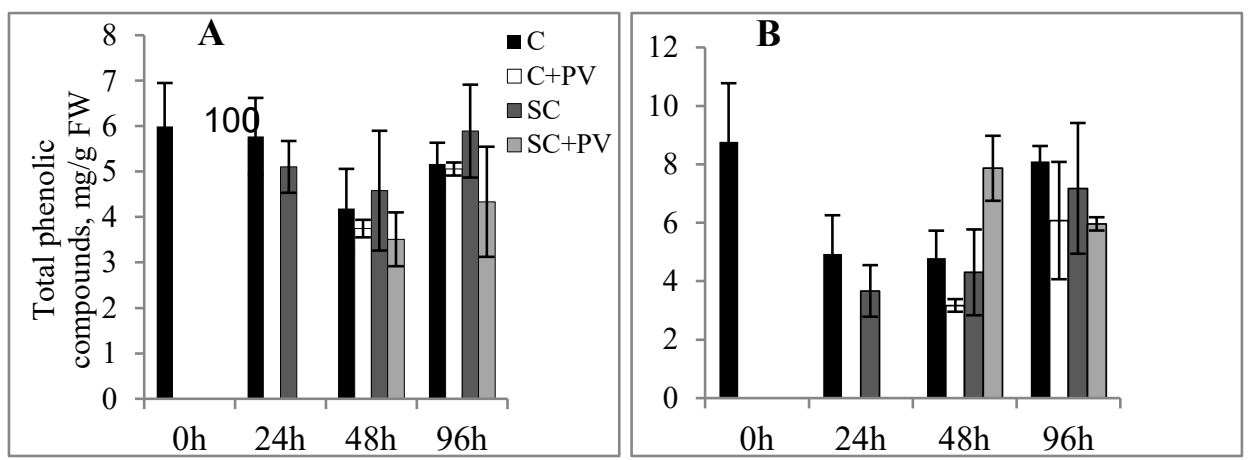

Fig. 3. Total phenols content in leaves of two grape cultivars: Vostorg (A) and Muscat blanc (B) under different conditions $(\mathrm{C}-$ control, $\mathrm{C}+\mathrm{PV}-$ control $+\mathrm{PV}$ infection, $\mathrm{SC}$ - pre-treatment with $\mathrm{SC}, \mathrm{SC}+\mathrm{PV}$ $-\mathrm{SC}$ pre-treatment $+\mathrm{PV}$ infection). Treatment time $-0,24,48,96$ hours.

The relative expression of stilbene synthase gene of the cultivar Vostorg increased only after 96 hours, moreover the maximum expression level was established for uninfected samples with SC pre-treatment (Fig. 4). Highest relative expression of lipoxygenase gene was detected in infected leaves of cv. Vostorg after 48 hours. After 96 hours, a slight increase of the relative expression of genes 9-LOX and PAL, compared to the data obtained after 48 hours, in samples pre-treated with SC was recorded. Control infected samples of cv. Muscat blanc showed the highest relative expression content of the genes STS, PAL, 9-LOX after 48 hours. The relative expression of PR2 proteins gene in infected leaves of cv. Vostorg pretreated with SC was identified only after 48 hours (Table 1). In the rest of treatment variants and in control conditions the relative expression of this gene was extremely low for both $\mathrm{cv}$. Muscat blanc and cv. Vostorg. Higher expression level, compared to the results on PR2 gene, was found in PR3 gene. The cultivar Vostorg was characterized by an increased PR3 gene expression after 96 hours. On the contrary, for cv. Muscat blanc this interval was characterized by the decline of the gene expression, excluding the infected control.
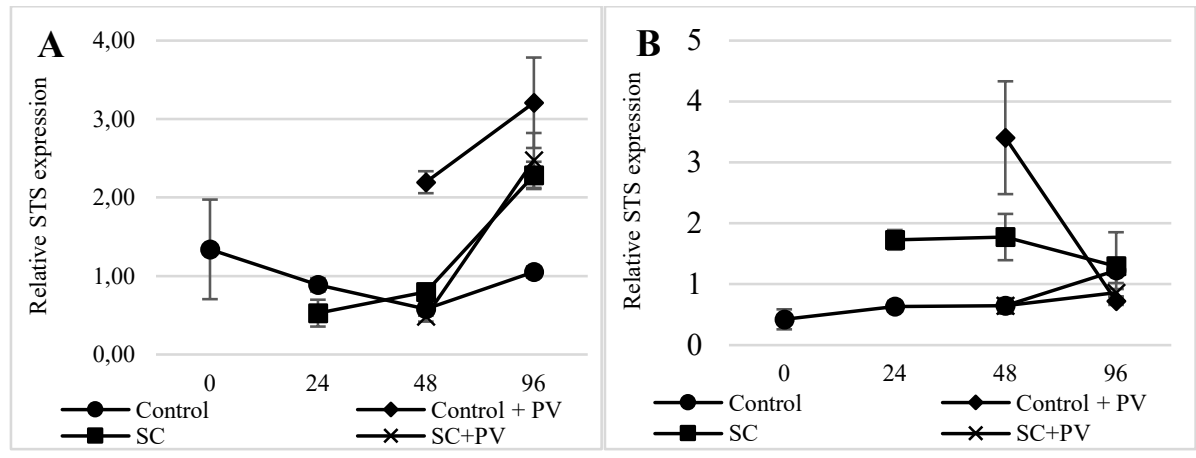

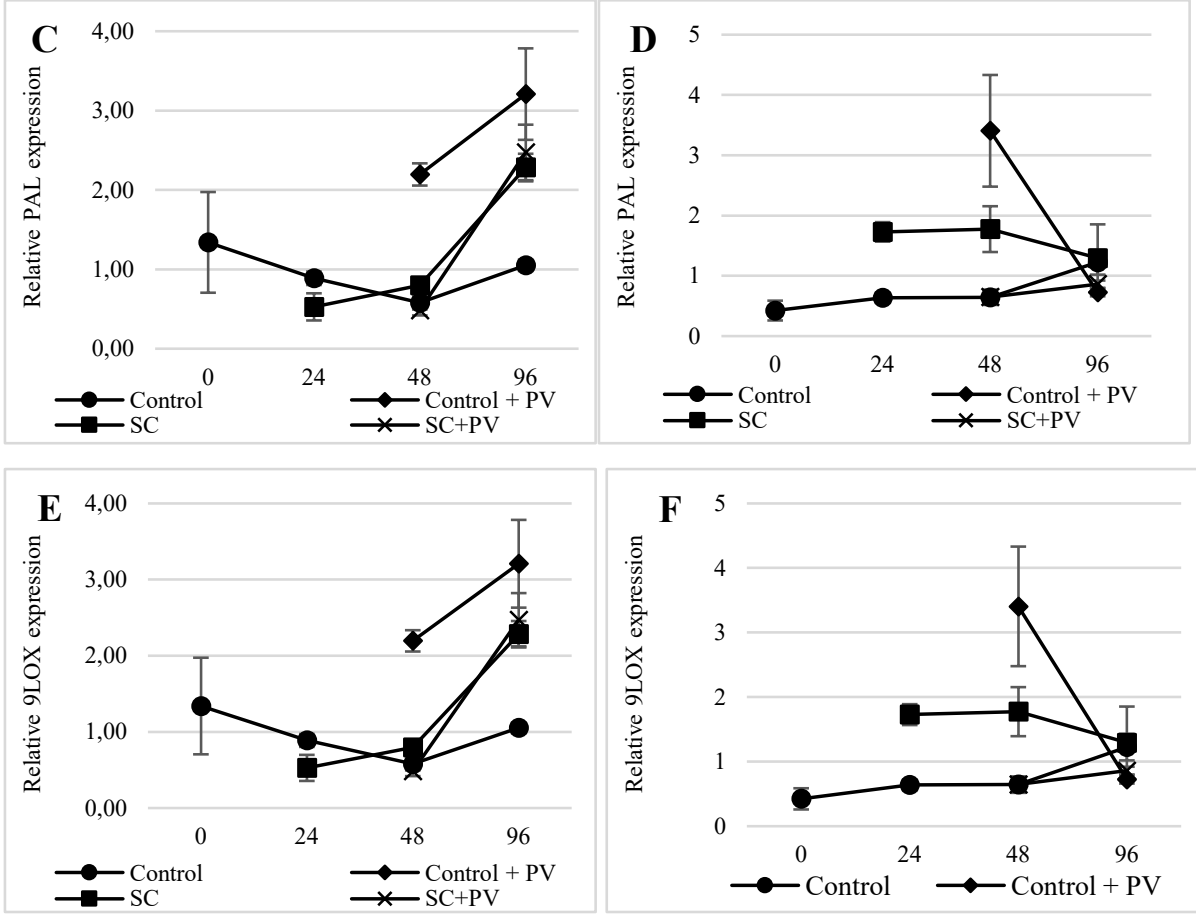

Fig. 4. Relative gene expression of STS, PAL, 9-LOX genes in leaves of two grape cultivars: Vostorg (A, C, E) and Muscat blanc (B, D, F) under different conditions. Treatment time - 0, 24, 48, 96 hours.

Table 1. Relative expression level of PR2 and PR3 proteins genes in leaves of two grape cultivars:

Vostorg and Muscat blanc under different conditions.

\begin{tabular}{|c|c|c|c|c|c|c|c|c|c|}
\hline \multirow{3}{*}{ Gene } & \multirow{3}{*}{$\begin{array}{l}\text { Treatment } \\
\text { time }\end{array}$} & \multicolumn{8}{|c|}{ Grape cultivars } \\
\hline & & \multicolumn{4}{|c|}{ Vostorg } & \multicolumn{4}{|c|}{ Muscat blanc } \\
\hline & & $\mathrm{C}$ & $\mathrm{C}+\mathrm{PV}$ & $\mathrm{SC}$ & $\mathrm{SC}+\mathrm{PV}$ & $\mathrm{C}$ & $\mathrm{C}+\mathrm{PV}$ & $\mathrm{SC}$ & $\mathrm{SC}+\mathrm{PV}$ \\
\hline \multirow{4}{*}{ PR2 } & $\mathrm{Oh}$ & 0.07 & & & & 0.03 & & & \\
\hline & $24 \mathrm{~h}$ & 0.15 & & 0.06 & & 0.09 & & 0.06 & \\
\hline & $48 \mathrm{~h}$ & 0.19 & 0.09 & 0.14 & 6.25 & 0.05 & 0.25 & 0.15 & 0.04 \\
\hline & $96 \mathrm{~h}$ & 0.18 & 0.35 & 0.27 & 0.28 & 0.02 & 0.05 & 0.06 & 0.08 \\
\hline \multirow{4}{*}{ PR3 } & $0 \mathrm{~h}$ & 3.53 & & & & 1.66 & & & \\
\hline & $24 \mathrm{~h}$ & 8.91 & & & & 2.94 & & 3.21 & \\
\hline & $48 \mathrm{~h}$ & 0.73 & 7.12 & 3.71 & 0.07 & 1.04 & 2.57 & 4.61 & 1.25 \\
\hline & $96 \mathrm{~h}$ & 4.57 & 7.33 & 8.91 & 4.63 & 0.51 & 3.96 & 1.23 & 1.03 \\
\hline
\end{tabular}

$\mathrm{C}-$ control, $\mathrm{C}+\mathrm{PV}-$ control $+\mathrm{PV}$ infection, $\mathrm{SC}-$ pre-treatment with $\mathrm{SC}, \mathrm{SC}+\mathrm{PV}-\mathrm{SC}$ pre-treatment $+\mathrm{PV}$ infection.

In variants with the pre-treatment of grape leaves with SC, significant decrease in the development of downy mildew was observed (Fig. 5). 


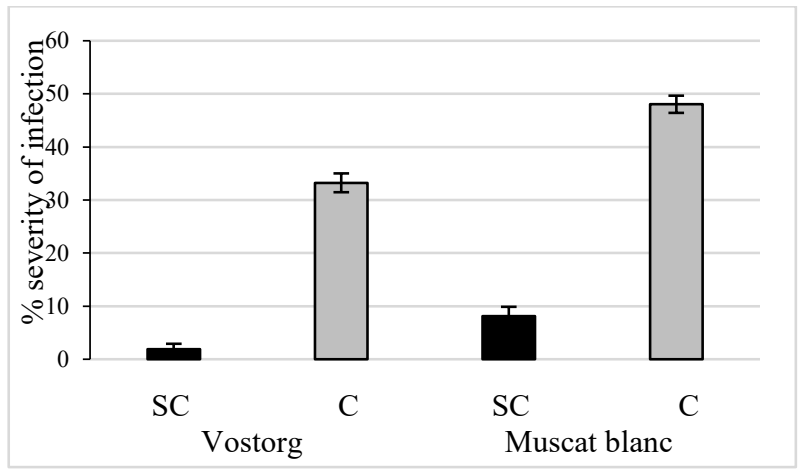

Fig. 5. The degree of severity of Plasmopara viticola infection in leaves of grape cultivars after 96 hours of inoculation. $\mathrm{C}$ - control, $\mathrm{SC}$ - pre-treatment with SC.

In the current study, the highly resistant cultivar Vostorg pre-treated with $S$. cerevisiae turned out to be less susceptible to the disease. It caused by the rapid increase of PR2 proteins gene expression ( $\beta$-1,3-glucanase) and elevated hydrogen peroxide content against a background of the low MDA content - one of the products of lipid peroxidation, on the first day after inoculation with Plasmopara viticola. Thus, cv. Vostorg induced synthesis of glucanases which was aimed to provide the line of defense against the pathogen without any visible signs of the oxidative stress (low MDA content compared to the control). On the second day after inoculation with downy mildew, PR3 proteins (chitinases) genes expression was observed, but it was lower compared to samples without SC pre-treatment.

For the susceptible cultivar Muscat blanc, pre-treatment with SC resulted in the increase of the total phenols content compared to the control and also in a slight increase in the relative expression of stilbene synthase gene on the first day after inoculation. Furthermore, this cultivar showed an increase of STS, LOX, PAL genes expression in the infected control on the first day after inoculation with subsequent decline of the parameter later on.

Thus, it was shown that susceptible cultivar induces plant's immune response to the nonpathogenic microorganism (yeasts) before the infection with downy mildew. This is determined by increasing gene expression of proteins which are involved in phytoalexins synthesis and accumulation. Pre-treatment, or priming, of leaves with symbiotes is one of the existing ways of plant protection from different diseases. Different bacterial strains are known induce grape tolerance to Botrytis cinerea by increasing stilbenes, salicylic acid, resveratrol and viniferin content [17].

\section{Conclusions}

Results of this study allow us to conclude that the treatment of grape leaves with symbiote of $S$. cerevisiae of both highly resistant and susceptible cultivars contributes to an increase in the level of immunity to this disease either by enhancing the immune response or by gradually accumulating the content of phytoalexins.

The work was supported by the Russian Foundation for Basic Research grant No. 19016-00210 A.

\section{References}

1. F. M. Freimoser, M. P. Rueda-Mejia, B. Tilocca, Q. Migheli, World J. Microbiol. Biotechnol. 35, 154 (2019). https://doi.org/10.1007/s11274-019-2728-4 
2. S. F. Fu, P. F. Sun, H. Y. Lu, J. Y. Wei, H. S. Xiao, W. T. Fang, B. Y . Cheng, J. Y. Chou, Fungal Biol., 120(3), 433-448 (2016). https://doi.org/10.1016/j.funbio. 2015.12.006

3. P. Nutaratat, N. Srisuk, P. Arunrattiyakorn, S. Limtong, Fungal Biol., 118(8), 683-694 (2014) https://doi.org/10.1016/j.funbio.2014.04.010

4. P.F. Sun, W.T. Fang, L.Y. Shin, J.Y. Wei, S.F. Fu, J.Y. Chou, PLoS One, 9(12), e114196 (2014). https://doi.org/10.1371/journal.pone.0114196

5. R.P. Rao, A. Hunter, O. Kashpur, J. Normanly, Genetics, 185 (1), 211-220 (2010). https://doi.org/10.1534/genetics.109.112854

6. M.M. Abdel-Kareem, A.M. Rasmey, A.A. Zohri, Lett. Appl. Microbiol., 68 (2), 104111 (2019). https://doi.org/10.1111/lam.13105

7. A. Fernandez-San Millan, I. Farran, L. Larraya, M. Ancin, L.M. Arregui, J. Veramendi, Microbiol. Research, 237, 126480 (2020). https://doi.org/10.1016/j.micres.2020.126480

8. R. Flamini, F. Mattivi, M.D. Rosso, P. Arapitsas, L. Bavaresco, Int. J. Molecul. Sci., 14(10), 19651-19669 (2013). https://doi.org/10.3390/ijms141019651

9. A. Vannozzi, D.C.J. Wong, J. Höll, I. Hmmam, J.T. Matus, J. Bogs, T. Ziegler, I. Dry, G. Barcaccia, M. Lucchin, Plant Cell Physiol., 59 (5), 1043-1059 (2018). https://doi.org/10.1093/pcp/pcy045

10. C.F. Wang, L.L. Huang, H.C. Zhang, Q.M. Han, H. Buchenauer, Z.S. Kang, Physiol. Mol. Plant Pathol, 74, 221-229 (2010). https://doi.org/10.1016/j.pmpp.2010.02.002

11. A. Ghasemzadeh, A. Nasiri, H.Z.E. Jaafar, A. Baghdadi, I. Ahmad, Molecules, 19, 17632-17648 (2014). https://doi.org/10.3390/molecules191117632

12. J.D. Castaño, J. Zhang, J.S. Schilling, J. Microbiol. Methods, 145, 10-13 (2018). https://doi.org/10.1016/j.mimet.2017.12.004

13. M.A. Sundyreva, I.V. Stepanov, I.I. Suprun, Ya.V. Ushakova, Sci. J. KubSAU. 143(09), 12 (2018). https://doi.org/10.21515/1990-4665-143-012

14. M. C. Dufour, C. Lambert, J. Bouscaut, J. M. Merillon, M. F. Corio-Costet, Plant Pathology, 62(2), 370-382 (2013). https://doi.org/10.1111/j.1365-3059.2012.02628.x

15. S. Pessina, L. Lenzi, M. Perazzolli, M. Campa, L. Dalla Costa, S. Urso, G. Valè, F. Salamini, R. Velasco, M. Malnoy, Horticulture Research, 3, 16016 (2016). https://doi.org/10.1038/hortres.2016.16

16. W. Dumin, M. Rostas, C. Winefield, Mol. Biol. Rep., 45, 263-277 (2018). https://doi.org/10.1007/s11033-018-4159-y

17. B.W.M. Verhagen, P. Trotel-Aziz, M. Couderchet, M. Hofte, A. Aziz, J. Exp. Bot., 61(1), 249-260 (2010). https://doi.org/10.1093/jxb/erp295 